\title{
Intracellular Esterase from Lactobacillus casei LILA: Nucleotide Sequencing, Purification, and Characterization
}

\author{
K. M. Fenster, K. L. Parkin, and J. L. Steele \\ Department of Food Science, \\ University of Wisconsin-Madison, \\ Madison 53706
}

\section{ABSTRACT}

An esterase gene (estC) was isolated from a genomic library of Lactobacillus casei LILA. The estC gene consisted of a $777 \mathrm{bp}$ open reading frame encoding a putative peptide of $28.9 \mathrm{kDa}$. A recombinant EstC fusion protein containing a C-terminal six-histidine tag was constructed and purified to electrophoretic homogeneity. Characterization of EstC revealed that it was a serine-dependent dimeric enzyme. Optimum temperature, $\mathrm{NaCl}$ concentration, and $\mathrm{pH}$ for EstC were determined to be $30^{\circ} \mathrm{C}, 0 \% \mathrm{NaCl}$, and $\mathrm{pH} 5.5$, respectively. EstC had significant activity under conditions simulating those of ripening cheese $\left(10^{\circ} \mathrm{C}, 4 \% \mathrm{NaCl}\right.$, and $\mathrm{pH}$ 5.1). Kinetic constants $\left(\mathrm{K}_{\mathrm{M}}\right.$ and $\left.\mathrm{V}_{\max }\right)$ were determined for EstC action on a variety of ethyl esters and ester compounds consisting of substituted phenyl alcohols and short $n$-chain fatty acids. For comparison purposes, the previously studied EstA from Lactococcus lactis MG1363 was purified to electrophoretic homogeneity and its substrate selectivity determined in a similar fashion. Different substrate selectivities were observed for EstC and EstA.

(Key words: Lactobacillus casei, esterase, nucleotide sequencing, purification)

\begin{abstract}
Abbreviation key: Ap = ampicillin, $\mathbf{a}_{\mathrm{W}}=$ water activity, $\mathbf{B Q L}$ = below quantifiable limits, $\mathbf{D F P}=$ diisopropyl fluorophosphate, FA = fatty acid, IAA = iodoacetic acid, IPTG = isopropyl-thio- $\beta$-D-galactoside, $\mathbf{L A B}=$ lactic acid bacteria, LB $=$ Luria-Bertani, $\mathbf{M E S}=2-(N$-morpholino)ethansulfonic acid, $\mathbf{M W}=$ molecular weight, $\mathbf{O R F}$ $=$ open reading frame, $\mathbf{P C M B}=p$-chloromercuribenzoic acid, $\mathbf{P G L}=$ pregastric lingual lipase, $\mathbf{P M S F}=$ phenylmethylsulfonyl fluoride, $\boldsymbol{p} \mathbf{N P}=p$-nitrophenyl, $\mathbf{X}$-Gal = 5 -bromo-4-chloro-3-indoyl- $\beta$-D-galactoside.
\end{abstract}

Received September 2, 2002.

Accepted October 25, 2002.

Corresponding author: J. L. Steele; e-mail: jlsteele@facstaff. wisc.edu.

\section{INTRODUCTION}

Flavor development in cheese is complex and different for each cheese variety (Fox et al., 2000). Milk fat is an essential component for the correct development and proper balance of flavors during cheese ripening (McSweeney and Sousa, 2000). Lipolysis of milk fat in cheese produces fatty acids (FA), which influence cheese flavor directly by imparting specific flavor notes, or indirectly as precursors for the formation of other flavor compounds (Woo and Lindsay, 1984; McSweeney and Sousa, 2000). Short $n$-chain FA, such as butanoate, hexanoate, and octanoate are important for the characteristic flavor of different cheese varieties and constitute the majority of volatile FA released from milk fat by lipases (EC 3.1.1.3) (Woo et al., 1984; Woo and Lindsay, 1984; Ha and Lindsay, 1993). The significance of short $n$-chain FA to cheese flavor is dependent upon the cheese variety as well as the concentration and balance of these flavors within the cheese (Woo et al., 1984; Woo and Lindsay, 1984). For example, elevated concentrations of butanoate and hexanoate are important for the development of FA flavors characteristic of aged Italian cheeses, such as Parmesan, Grana Padano, Romano, and Provolone (Woo et al., 1984; Woo and Lindsay, 1984). Short $n$-chain FA can also contribute to cheese flavor development by becoming esterified to ethanol to produce flavorful ethyl esters (Ha and Lindsay, 1992; McSweeney and Sousa, 2000). In Parmesan and Grana Padano cheeses, ethyl butanoate and ethyl hexanoate are believed to play an important role in the formation of the characteristic fruity flavors associated with these cheese varieties (Dumont et al., 1974; Meinhart and Schreier, 1986; Barbieri et al., 1994; Moio and Addeo, 1998).

Lipolytic enzymes involved in flavor development of Italian-type cheeses originate from milk, starter and nonstarter lactic acid bacteria (LAB), and pregastric tissues of ruminants (Fox et al., 1995; McSweeney and Sousa, 2000). Milk lipase is abundant in raw milk and could contribute to lipolysis in cheese manufactured from unpasteurized milk (Fox et al., 1995; McSweeney and Sousa, 2000). However, when pasteurized milk is 
used, milk lipase is inactivated and unlikely to contribute to cheese flavor (Fox et al., 1995; McSweeney and Sousa, 2000). Pregastric lingual lipases (PGL) from calf, kid, and lamb, are used in the manufacture of Romano and Provolone cheese (Fox et al., 1995; McSweeney and Sousa, 2000). Use of PGL in these cheeses result in extensive lipolysis of milk fat which contributes to development of sharp, peppery, and "picante" flavor notes (Johnson, 2001). However, PGL is not used to make Parmesan and Grana Padano, which are characterized by mellow fatty acid and fruity flavor notes (Ha and Lindsay, 1992; Barbieri et al., 1994; Johnson, 2001).

Little is known about the contribution of lipases and esterases (EC 3.1.1.6) from LAB to the formation of cheese flavor in Italian-type cheeses, such as Parmesan and Grana Padano (Gobbetti et al., 1997a; Gobbetti et al., 1997b). Presumably, esterases and lipases from starter LAB, such as Lb. helveticus, Lb. delbrueckii, Lb. fermentum, and Streptococcus thermophilus, and nonstarter LAB, such as $L b$. casei, are responsible for liberating short $n$-chain fatty acids from milk fat at elevated water activity $\left(\mathrm{a}_{\mathrm{w}}\right)$ and synthesis of short $n$ chain ethyl esters as $\mathrm{a}_{\mathrm{w}}$ decreases with ripening (Ha and Lindsay, 1992; Liu et al., 1998; Johnson, 2001). Given the high cell densities reached by starter and nonstarter lactobacilli ( $10^{8}$ to $10^{9} \mathrm{cfu} / \mathrm{g}$ cheese) as well as the long ripening time associated with these cheeses, lipases and esterases from LAB are likely to play an important role in flavor development of these cheeses (Gobbetti et al., 1996a; Beresford et al., 2001).

The esterolytic and lipolytic activities of several thermophilic and mesophilic lactobacilli have been described (Gobbetti et al., 1996a). Esterases and lipases of LAB have recently been characterized from $L b$. casei (Castillo et al., 1999), Lb. plantarum (Gobbetti et al., 1996b; Gobbetti et al., 1997a), Lb. fermentum (Gobbetti et al., 1997b), Lb. helveticus (Fenster et al., 2000), Lc. lactis (Tsakalidou and Kalantzopoulos, 1992; Holland and Coolbear, 1996; Chich et al., 1997; Fernández et al., 2000), and St. thermophilus (Liu et al., 2001). Properties and substrate selectivities of some of these esterases and lipases suggest that these enzymes could have a significant effect on cheese flavor development.

This manuscript describes the biochemical characterization of an esterase, designated EstC, from $L b$. casei LILA. The substrate selectivity of purified esterase, EstA, from Lc. lactis MG1363 (Fernández et al., 2000) was determined in a similar fashion for comparison. Both EstC and EstA were observed to have similar activities towards ethyl esters, such as ethyl butanoate and ethyl hexanoate. EstC and EstA were compared to determine if they shared a common mechanism or molecular basis for selectivity for ethyl ester hydrolysis.
The potential roles of EstC and EstA in cheese flavor development is discussed based on their sensitivity to environmental conditions encountered in ripening cheese and their substrate selectivities.

\section{MATERIALS AND METHODS}

\section{Bacterial Strains, Media, and Plasmids}

Lb. casei LILA was obtained from the University of Wisconsin Center for Dairy Research Culture Collection. Escherichia coli DH5 $\alpha$ (Gibco-BRL Life Technologies, Inc., Gaithersburg, MD) and TOP $10 \mathrm{E}$. coli cells (Invitrogen Corporation/Novex, Carlsbad, CA) were grown in Luria-Bertani $(\mathbf{L B})$ broth at $37^{\circ} \mathrm{C}$ with aeration (Sambrook et al., 1989). Lb. casei strains were grown in MRS broth at $37^{\circ} \mathrm{C}$ without shaking (De Man et al., 1960). Lc. lactis was grown at $30^{\circ} \mathrm{C}$ in M17 broth (Difco Laboratories, Detroit, MI) supplemented with $0.5 \%$ (wt/vol) glucose without shaking. Agar plates were prepared by adding $1.5 \%$ (wt/vol) granulated agar (Difco Laboratories, Detroit, MI) to liquid media. The concentrations of antibiotics added to liquid media or agar plates for selection of plasmids were as follows: pUC18 (Gibco-BRL), $100 \mu \mathrm{g}$ of ampicillin (Ap) /ml; pMOB (Gold Biotechnology, St. Louis, MO), $100 \mu \mathrm{g}$ of Ap or $100 \mu \mathrm{g}$ of carbenicillin /ml; pQE-12 (Qiagen, Inc., Chatsworth, CA), $100 \mu \mathrm{g}$ of Ap/ml; pQE-8 (Qiagen), $100 \mu \mathrm{g}$ of Ap /ml; and pREP-4 (Qiagen), $25 \mu \mathrm{g}$ of kanamycin/ $\mathrm{ml}$. All antibiotics were obtained from Sigma Chemical Co. (St. Louis, MO). For experiments utilizing $\alpha$-complementation, isopropyl-thio- $\beta$-galactoside (IPTG) (Gibco-BRL) and 5-bromo-4-chloro-3-indoyl- $\beta$-D-galactoside (X-Gal) (Gibco-BRL) were added to agar media at concentrations of 119 and $40 \mathrm{mg} / \mathrm{L}$, respectively.

\section{Screening of Lb. casei LILA Genomic Library}

Previously, a genomic library of $L b$. casei LILA was constructed in $E$. coli Top 10 cells using the vector pUC18. Briefly, chromosomal DNA from $L b$. casei LILA was partially digested with Sau3A and 4.5 to 9.0 kilobase pair (kbp) fragments were isolated from low-melting agarose gels (Gibco-BRL) using QIAquick Gel Extraction Kit (Qiagen). The vector pUC-18 was digested with BamHI, treated with alkaline phosphatase, and ligated with the 4.5 to $9.0 \mathrm{kbp}$ Sau3A chromosomal fragments. One Shot TOP 10 chemically competent $E$. coli cells (Invitrogen) were transformed with the ligation products as per the manufacturer's instructions. Cells of the library were plated onto LB plates containing Ap such that 50 to 100 colonies were visible after overnight growth. Esterase activity was detected using a pour plate enzyme assay in which $15 \mathrm{ml}$ of $50 \mathrm{~m} M$ HEPES (pH 7.0) (Sigma), $6 \mathrm{~m} M$ Fast Garnet GBC (Sigma) and 
$1.0 \mathrm{~m} M \beta$-naphthyl butanoate or $\beta$-naphthyl octanoate were added to each plate and then incubated for $15 \mathrm{~min}$ at $25^{\circ}$ C. Lb. casei LILA and E. coli Top 10 (pUC-18) were used as positive and negative controls, respectively. The appearance of an intense red color around colonies (resulting from release of $\beta$-naphthol and subsequent reaction with Fast Garnet GBC) within 15 min was taken as a positive indication of esterase activity.

\section{Molecular Cloning}

Recombinant DNA techniques were performed essentially as described by Sambrook et al. (1989). T4 DNA ligase, alkaline phosphatase, and restriction endonucleases were used as recommended by the manufacturer (Gibco-BRL). E. coli DH5 $\alpha$ transformations were performed with a Gene Pulser following the instructions recommended by the manufacturer (Bio-Rad Laboratories, Richmond, CA). Tn1000 mutagenesis was performed as recommended by the manufacturer (Gold Biotechnology). Pour plate enzyme assays with Fast Garnet GBC and $\beta$-naphthyl butanoate or $\beta$-naphthyl octanoate were conducted to determine which Tn1000 insertions lacked esterase activity.

\section{DNA Sequencing and Sequence Analysis}

Nested sets of $\operatorname{Tn} 1000$ insertions were generated in estC with the Tn1000 kit (Gold Biotechnology). DNA templates were isolated using the modified alkaline lysis/polyethylene glycol precipitation procedure described by Applied Biosystems, Inc. (Foster City, CA). Vector and transposon-specific primers were supplied with the Tn1000 kit. Additional primers were designed using the Affinity program supplied by Ransom Hill Bioscience, Inc. (Ramona, CA), and were synthesized by Gibco-BRL Custom Primers (Grand Island, NY). Cycle sequence reactions were performed in a Perkin-Elmer model 480 thermal cycler (The Perkin-Elmer Corp., Norwalk, CT) using Prism BigDye Terminator Cycle Sequencing Kit (Applied Biosystems). DNA sequence determination was performed by the Nucleic Acid and Protein Facility of the University of Wisconsin Biotechnology Center, using an ABI Prism 377XL DNA Automated Sequencer. DNA sequences were analyzed using Lasergene 5.0 program of DNASTAR, Inc. (Madison, WI). Protein identity and amino acid sequence motif searches were performed using the BLAST network service (Altschul et al., 1990) and the PROSITE Dictionary of Protein Sites and Patterns (Hofmann et al., 1999), respectively. Protein sequence alignment was performed with the MEGALIGN program of Lasergene 5.0 (DNASTAR) and the program ALIGN (Person et al., 1997) from the Institut de Génétique Humaine.

\section{Purification of LILA EstC and MG1363 EstA}

The estC gene was amplified by PCR with Platinum Pfx DNA polymerase (Gibco-BRL) and 5' and 3' estC primers which contained a BamHI restriction site on the 5' end of each primer. The nucleotide sequences of the 5' and 3' primers were 5'cgggatcc TCTGAGTACA TTACTGTA3' and 5'cgggatccGCGAGCGACTGTTTC GAT3', respectively (nucleotides in lowercase letters were added in order to introduce the underlined BamHI sites).

A late-log phase culture (100 ml) of Lc. lactis MG1363 was lysed as described by Anderson and McKay (1983) and chromosomal DNA was isolated from this lysate using the method described by Marmur (1961). The estA gene was amplified from chromosomal DNA by PCR with Platinum Pfx DNA polymerase (Gibco-BRL) and 5' and 3' estA primers which contained a BamHI restriction site on the 5' end of each primer. The nucleotide sequences of the 5' and 3' primers, which were designed from the nucleotide sequence of estA (GenBank accession number AF157601), were 5'cgggatcc G CAGTAATCAATATCGAATAC3' and 5'cgggatccTTA ACTCAATCGTTCTTCTTG3', respectively (nucleotides in lowercase letters were added in order to introduce the underlined BamHI sites).

The PCR products for estC and estA were digested with $B a m \mathrm{HI}$ and cloned into the BamHI site of $\mathrm{pQE}$ 12 and $\mathrm{pQE}-8$, respectively. The ligation mixtures were transformed into E. coli DH5 $\alpha$ (pREP-4). Plasmids containing successful fusions between the estC and estA structural genes and the $(\mathrm{His})_{6}$ encoding region of $\mathrm{pQE}$ 12 and pQE-8, respectively, were identified by restriction analysis, enzyme assays, and DNA sequencing of est $C$ and estA. Enzyme assays were conducted after inducing expression of the plasmid-encoded estC and est $A$ genes by growing cells in LB broth containing 2.0 $\mathrm{m} M$ IPTG.

Purification of EstC and EstA was performed using the QIAexpressionist Protein Purification System (Qiagen) according to the manufacturer's instructions. The one step purification method is based on affinity of the $(\mathrm{His})_{6}$ tag for Ni-nitrilotriacetic acid, desorbing non (His) $)_{6}$ tagged proteins with $50 \mathrm{~m} M$ Na-phosphate $(\mathrm{pH}$ 8.0), $300 \mathrm{~m} M \mathrm{NaCl}$, and $10 \mathrm{~m} M$ histidine, and then eluting the target protein with a gradient of histidine from 10 to $500 \mathrm{mM}$. Protein profiles in collected fractions were visualized on vertical $12 \%$ SDS-PAGE gels (Sambrook et al., 1989). Fractions containing EstC(His) $)_{6}$ or EstA-(His) $)_{6}$ were pooled and dialyzed against $50 \mathrm{~m} M$ Na-phosphate (pH 8.0) and $300 \mathrm{mM} \mathrm{NaCl}$ at $4^{\circ} \mathrm{C}$.

\section{Substrate Specificity of LILA EstC and MG1363 EstA}

The substrate selectivities of EstC and EstA were examined with a series of substituted $p$-nitrophenyl 
Table 1. Hydrolysis of various esters by purified Lactobacillus casei LILA EstC and Lactococcus lactis MG1363 EstA.

\begin{tabular}{|c|c|c|c|c|c|c|}
\hline \multirow[b]{2}{*}{ Substrate } & \multicolumn{3}{|c|}{ EstC } & \multicolumn{3}{|c|}{ EstA } \\
\hline & $\mathrm{K}_{\mathrm{M}}^{1}$ & $\mathrm{~V}_{\max }^{2}$ & $\mathrm{~V}_{\max } / \mathrm{K}_{\mathrm{M}}$ & $\mathrm{K}_{\mathrm{M}}$ & $\mathrm{V}_{\max }$ & $\mathrm{V}_{\max } / \mathrm{K}_{\mathrm{M}}$ \\
\hline \multicolumn{7}{|l|}{$p$-Nitrophenyl esters } \\
\hline$p$ NP-acetate ${ }^{3}$ & 0.077 & 17 & 220 & 0.47 & 23 & 49 \\
\hline$p \mathrm{NP}$-propionate & 0.12 & 90 & 750 & 0.67 & 62 & 93 \\
\hline$p$ NP-butanoate & 0.097 & 63 & 650 & 0.28 & 58 & 210 \\
\hline$p$ NP-pentanoate & 0.12 & 26 & 220 & 0.079 & 39 & 490 \\
\hline$p$ NP-hexanoate & 0.034 & 3.4 & 100 & 0.12 & 62 & 520 \\
\hline$p$ NP-octanoate & $\mathrm{BQL}^{4}$ & $\mathrm{BQL}$ & $\mathrm{BQL}$ & 0.072 & 22 & 310 \\
\hline$p$ NP-decanoate & BQL & $\mathrm{BQL}$ & $\mathrm{BQL}$ & 0.032 & 8.3 & 260 \\
\hline$p$ NP-dodecanoate & BQL & $\mathrm{BQL}$ & $\mathrm{BQL}$ & 0.0038 & 0.91 & 240 \\
\hline$p$ NP-C14 to C16 & $\mathrm{BQL}$ & $\mathrm{BQL}$ & $\mathrm{BQL}$ & $\mathrm{BQL}$ & $\mathrm{BQL}$ & $\mathrm{BQL}$ \\
\hline \multicolumn{7}{|l|}{ Ethyl esters } \\
\hline ethyl acetate & 39 & 2.8 & 0.072 & $\mathrm{BQL}$ & BQL & $\mathrm{BQL}$ \\
\hline ethyl propionate & 10 & 15 & 1.5 & $\mathrm{BQL}$ & $\mathrm{BQL}$ & $\mathrm{BQL}$ \\
\hline ethyl butanoate & 6.8 & 15 & 2.2 & 62 & 23 & 0.37 \\
\hline ethyl pentanoate & 6.6 & 8.7 & 1.3 & 19 & 21 & 1.1 \\
\hline ethyl hexanoate & 2.8 & 2.3 & 0.83 & 7.5 & 27 & 3.6 \\
\hline \multicolumn{7}{|l|}{ Acetic acid esters } \\
\hline propyl acetate & 6.0 & 1.4 & 0.23 & BQL & BQL & $\mathrm{BQL}$ \\
\hline butyl acetate & 3.4 & 0.67 & 0.20 & BQL & BQL & BQL \\
\hline hexanoyl acetate & 0.19 & 0.45 & 2.4 & BQL & $\mathrm{BQL}$ & $\mathrm{BQL}$ \\
\hline phenyl acetate & 0.93 & 5.7 & 6.1 & 35 & 15 & 0.43 \\
\hline phenylthioacetate & 0.42 & 4.5 & 11 & 13 & 8.8 & 0.68 \\
\hline \multicolumn{7}{|l|}{${ }^{1} \mathrm{~m} M$} \\
\hline \multicolumn{7}{|l|}{${ }^{2} \mu \mathrm{mol} / \mathrm{mg} / \mathrm{ml}$} \\
\hline \multicolumn{7}{|c|}{${ }^{3} p \mathrm{NP}=p$-Nitrophenyl. } \\
\hline
\end{tabular}

( $\boldsymbol{p N P}$ ), ethyl, and acetate ester compounds using a standard assay mixture. The standard assay mixture for EstC was a composite buffer consisting of $20 \mathrm{mM}$ (each) HEPES, MES, malic acid, and boric acid (pH 5.5). A similar standard assay mixture was used for EstA except $2.5 \% \mathrm{NaCl}$ was added and the $\mathrm{pH}$ was adjusted to 7.5. The standard assay mixtures were $\mathrm{pH}$-adjusted at the temperatures used for the enzyme assays. Assays were conducted at $25^{\circ} \mathrm{C}$ for EstC and $30^{\circ} \mathrm{C}$ for EstA. Reaction mixtures ( $1 \mathrm{ml}$ total reaction volume) were preequilibrated for $5 \mathrm{~min}$ at $25^{\circ} \mathrm{C}$ (for EstC) and $30^{\circ} \mathrm{C}$ (for EstA) prior to initiation of reactions. Reactions were initiated with purified EstC or EstA at protein concentrations of 0.17 to $2.2 \mu \mathrm{g}$ protein $/ \mathrm{ml}$. Control reactions containing no enzyme were utilized to account for any spontaneous hydrolysis of the substrates tested. Measured reaction rates were verified to be linear under these conditions. Enzyme assays were performed twice in duplicate and the coefficient of variation was $\leq 5 \%$. Kinetic constants $\left(\mathrm{K}_{\mathrm{M}}\right.$ and $\left.\mathrm{V}_{\max }\right)$ were calculated from the Hyperbola (Hyperbol.fit) program of Sigma Plot 3.0 (Jandel Scientific Software, San Rafael, CA). The specific activities of EstC and EstA were expressed as $\mu \mathrm{mol}$ product ( $p$-nitrophenol, ethanol, and acetate)/min/mg of protein.
Purified EstC and EstA were each assayed with varying concentrations ( 0.0039 to $4.0 \mathrm{mM}$ ) of $p \mathrm{NP}$ esters of C2-C16 fatty acids (Table 1). Enzyme assays were run continuously for 5 minutes and initial rates of $p$-nitrophenol released by EstC and EstA were quantified by measuring absorbance at 340 and $400 \mathrm{~nm}$, respectively (assay $\mathrm{pH}$ was different). The extinction coefficients $\left(\varepsilon_{\mathrm{m} M}\right)$ of $p$-nitrophenol under these conditions were determined to be $9.65 / \mathrm{cm}$ at $340 \mathrm{~nm}$ and $22.5 / \mathrm{cm}$ at 400 $\mathrm{nm}$.

Purified EstC and EstA were assayed with ethyl esters (Sigma) of C2 to C6 fatty acids and acetate esters such as propyl acetate, butyl acetate, hexanoyl acetate, phenylacetate, and phenylthioacetate over a range of concentrations (1.0 to $300 \mathrm{mM}$ ). Enzyme assays were conducted for 10 minutes and terminated by boiling for $3 \mathrm{~min}$. Reaction rates were quantified on the basis of release of ethanol or acetate using Ethanol or Acetate Detection Kits provided by R-Biopharm, Inc. (Marshall, MI).

\section{Characterization of LILA EstC and MG1363 EstA}

Determination of optimum temperature, $\mathrm{NaCl}$ concentration, and $\mathrm{pH}$ for EstC and EstA employed the 
standard assays described above using $p$ NP-butanoate as the substrate. The extinction coefficient $\left(\varepsilon_{\mathrm{m} M}\right)$ of $p$ nitrophenol was determined experimentally for each change in assay conditions. Absorbances were read at 340 and $400 \mathrm{~nm}$ at $\mathrm{pH}$ values lower and higher than 7.0, respectively (Martin et al., 1959). Enzyme activities were compared between conditions simulating those of ripening cheese $\left(10^{\circ} \mathrm{C}, 4 \% \mathrm{NaCl}, \mathrm{pH} 5.1\right)$ and optimal conditions for $\mathrm{EstC}\left(30^{\circ} \mathrm{C}, 0 \% \mathrm{NaCl}, \mathrm{pH} 5.5\right)$ and EstA $\left(45^{\circ} \mathrm{C}, 12.5 \% \mathrm{NaCl}, \mathrm{pH} 8.0\right)$.

Inhibitor studies of EstC and EstA employed the standard assay described above with $p$ NP-butanoate as the substrate. The inhibitors (Sigma) tested were EDTA, 1,10-phenanthroline, phenylmethylsulfonyl fluoride (PMSF), diisopropyl fluorophosphate (DFP), Pepstatin A, iodoacetic acid (IAA), and $p$-chloromercuribenzoic acid (PCMB). Inhibitors were incubated with $0.56 \mu \mathrm{g}$ protein $/ \mathrm{ml} \mathrm{EstC}$ and $0.23 \mu \mathrm{g}$ protein $/ \mathrm{ml} \mathrm{EstA}$ at a final concentration of $1 \mathrm{~m} M$ for 5 min prior to initiation of assays.

The native molecular weight (MW) of EstC and EstA was estimated by gel filtration as previously described (Fenster et al., 2000).

The isoelectric point of EstC and EstA was measured as previously described (Fenster et al., 2000). However, the individual isoelectric point standards of $\beta$-lactoglobulin (5.1), bovine carbonic anhydrase II (5.4 and 5.9), human carbonic anhydrase I (6.6), horse heart myoglobin (6.8 and 7.2), lentil lectin (8.2, 8.6, and 8.8), and trypsinogen (9.3) were also used.

\section{Nucleotide Sequence Accession Number}

The nucleotide sequence for estC has been submitted to GenBank and assigned the accession number AF506279.

\section{RESULTS}

\section{Detection and Isolation of estC}

One clone, designated DH5 $\alpha$ (pSUW909), from the Lb. casei LILA genomic library was observed to hydrolyze $\beta$-naphthyl butanoate. Activity of this clone with $\beta$-naphthyl octanoate was below quantifiable limits (BQL). The esterase activity encoded by pSUW909 was designated EstC. A restriction map of the 8.0-kbp chromosomal insert of pSUW909 was made (data not shown), and a 1.5-kbp KpnI fragment was subcloned in pMOB. E. coli DH5 $\alpha$ containing this construct, designated pSUW910, expressed EstC activity and was further characterized. Inactivation of estC by insertions of Tn1000 within the 1.5-kbp insert of pSUW910 revealed that estC was approximately $0.75 \mathrm{kbp}$ in length (data not shown).

\section{Sequence Analysis of LILA EstC}

Approximately $1.5 \mathrm{kbp}$ of the pSUW910 insert was sequenced and an open reading frame (ORF) of $777 \mathrm{bp}$, designated estC, was identified (Figure 1). The ORF could encode a polypeptide of 259 amino acid residues with a deduced mass of $28.9 \mathrm{kDa}$. The ORF start codon is preceded by a putative ribosome binding site (AGGAGG; nucleotides -13 to -8 ) and putative -10 (TATAAT; nucleotides -41 to -36 ) and -35 (TTCGTG; nucleotides -66 to -61 ) promoters (Shine and Dalgarno, 1974). No rho-independent transcriptional terminator was identified in the 3' noncoding region of estC. No ORFs were identified in the $500 \mathrm{bp}$ sequence upstream from $e s t C$ or the $300 \mathrm{bp}$ downstream from estC on the EstC coding strand. Analysis of the ORF indicated that EstC lacks a classical secretion signal sequence (Izard and Kendall, 1994) at the N-terminus of the protein. The amino acid sequence GGSLG, starting at residue 93, fits the GXSXG motif found in most bacterial esterases and lipases (Jaeger et al., 1999).

Protein sequence searches using BLAST (Altschul et al., 1990) revealed that EstC had 28\% and 27\% sequence identity with a probable hydrolase from $\mathrm{Pseu}$ domonas aeruginosa (Stover et al., 2000) and a putative arylesterase from Bacillus subtilis (Kunst et al., 1997), respectively. The protein sequence searches using BLAST did not find significant homology between the Lb. casei LILA EstC and Lb. helveticus CNRZ32 EstA (Fenster et al., 2000) and Lc. lactis MG1363 EstA (Fernández et al., 2000). EstC was aligned with the CNRZ32 EstA and MG1363 EstA protein sequences and found to have $16.5 \%$ and $18.4 \%$ identity with these esterases, respectively.

\section{Purification of LILA EstC and MG1363 EstA}

Cloning of estC and estA into pQE-12 and pQE-8, respectively, resulted in plasmids designated pSUW911 and pSUW912. The orientation of the inserts was confirmed by restriction analysis. DNA sequence analysis of pSUW911 and pSUW912 confirmed that estC and estA were cloned in frame with the downstream and upstream (His) ${ }_{6}$-encoding region of $\mathrm{pQE}-12$ and $\mathrm{pQE}$ 8 , respectively, and no mutations had occurred in the nucleotide sequences during routine propagation in $E$. coli. After induction of EstC and EstA expression in DH5 $\alpha$ (pSUW911) and DH5 $\alpha$ (pSUW912) with IPTG, the overexpression and enzyme activity of EstC and EstA in cell-free extracts were evaluated by SDS-PAGE analysis and enzyme assays with $p$ NP-butanoate. EstC and EstA were subsequently purified to electrophoretic homogeneity (Figure 2) by affinity chromatography. 


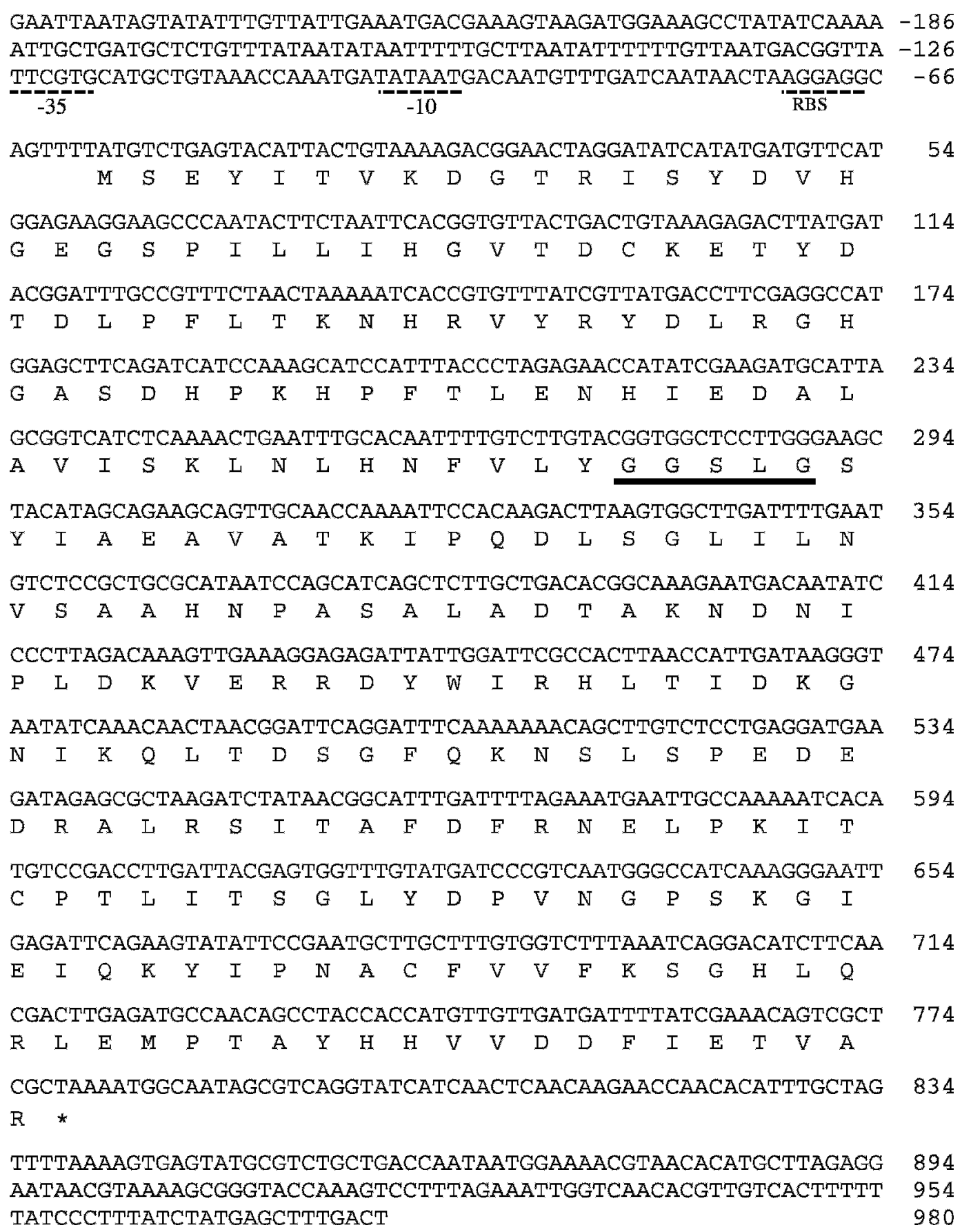

Figure 1. Nucleotide sequence of estC from Lactobacillus casei LILA. The predicted amino acid sequence is given below the nucleotide sequence in single-letter code. The putative ribosome binding site and putative -35 and -10 promoter sequences, are indicated with dashed lines. The stop codon is marked by an asterisk. The lipase/esterase active-site serine consensus sequence is underlined with a solid line.

\section{Characterization of LILA EstC and MG1363 EstA}

The monomeric MW of EstC and EstA was estimated under protein denaturing conditions (SDS-PAGE) to be $29.0 \pm 1.0 \mathrm{kDa}$ and $30.0 \pm 1.0 \mathrm{kDa}$, respectively (Figure 2 ). The native MW of EstC and EstA was estimated to be
$63 \pm 2.5 \mathrm{kDa}$ and $63 \pm 2.0$, respectively, by gel filtration, which suggests that both of these enzymes are homodimers under nondenaturing conditions. Isoelectric focusing of EstC and EstA resulted in single protein bands corresponding to isoelectric point values of $7.1 \pm 0.1$ and $5.2 \pm 0.1$, respectively. 


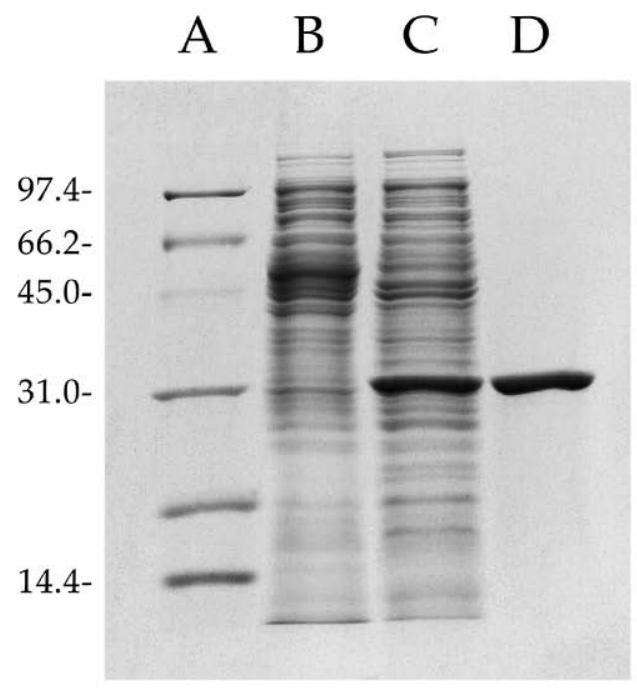

A

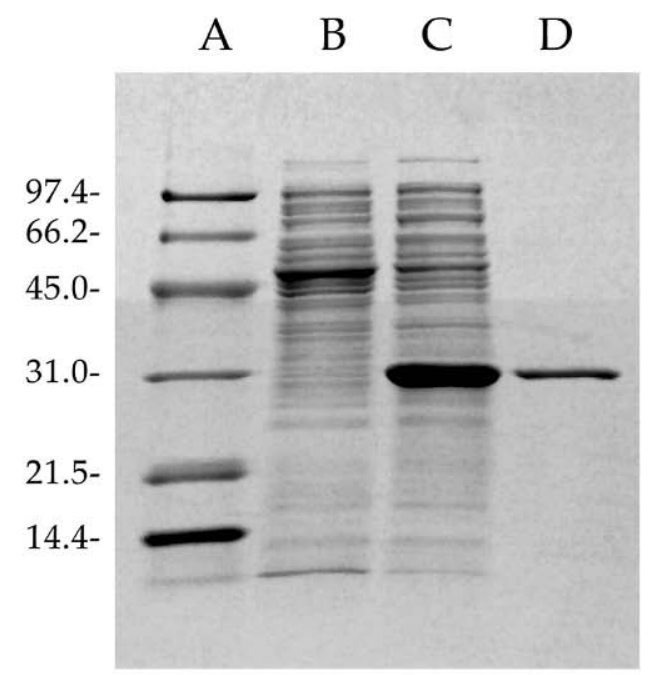

B

Figure 2. SDS-PAGE gels of purified Lactobacillus casei LILA EstC (Panel A) and Lactococcus lactis MG1363 EstA (Panel B). A. Lane A: protein standards (phosphorylase B, $97.4 \mathrm{kDa}$; bovine serum albumin, $66.2 \mathrm{kDa}$; ovalbumin, $45.0 \mathrm{kDa}$; carbonic anhydrase, $31.0 \mathrm{kDa}$; soybean trypsin inhibitor, $21.5 \mathrm{kDa}$; lysozyme, $14.4 \mathrm{kDa}$ ); lane B: cell-free extracts $(15 \mu \mathrm{g}$ protein) of DH5 $\alpha$ (pSUW911) grown in the absence of IPTG; lane C: cell-free extracts (15 $\mu \mathrm{g}$ protein) of DH5 $\alpha$ (pSUW911) grown in the presence of $2.0 \mathrm{~m} M$ IPTG; lane D: purified EstC (1.5 $\mu \mathrm{g}$ of protein). B. Lane A: protein standards (phosphorylase B, $97.4 \mathrm{kDa}$; bovine serum albumin, $66.2 \mathrm{kDa}$; ovalbumin, $45.0 \mathrm{kDa}$; carbonic anhydrase, $31.0 \mathrm{kDa}$; soybean trypsin inhibitor, $21.5 \mathrm{kDa}$; lysozyme, $14.4 \mathrm{kDa}$ ); lane B: cell-free extracts (15 $\mu \mathrm{g}$ protein) of DH5 $\alpha$ (pSUW912) grown in the absence of IPTG; lane C: cell-free extracts (15 $\mu \mathrm{g}$ protein) of DH5 $\alpha$ (pSUW912) grown in the presence of $2.0 \mathrm{~m} M$ IPTG; lane D: purified EstA (1.5 $\mu \mathrm{g}$ of protein).

The optimum temperatures for activity of EstC and EstA were $30^{\circ} \mathrm{C}$ and $45^{\circ} \mathrm{C}$, respectively, with specific activities of $40.0 \pm 0.2$ and $37.0 \pm 0.1 \mu \mathrm{mol} p$-nitrophenol/ $\mathrm{min} / \mathrm{mg}$ of protein. The activation energy of EstC and EstA over the range of 5 to $40^{\circ} \mathrm{C}$ and 5 to $50^{\circ} \mathrm{C}$ was calculated using Arrhenius plots to be 9.1 and $6.5 \mathrm{kcal} /$ mol, respectively (data not shown). Similarly, the energy of deactivation of EstC and EstA over the range 45 to $60^{\circ} \mathrm{C}$ and 55 to $70^{\circ} \mathrm{C}$ was determined to be 50.7 and $49.3 \mathrm{kcal} / \mathrm{mol}$, respectively.

The optimum $\mathrm{NaCl}$ concentration for EstC at $25^{\circ} \mathrm{C}$ and EstA at $30^{\circ} \mathrm{C}$ was $0 \%$ and $12.5 \%$ respectively, which corresponded to specific activities of $48.8 \pm 0.5$ and 51.0 $\pm 0.5 \mu \mathrm{mol} p$-nitrophenol $/ \mathrm{min} / \mathrm{mg}$ of protein. The specific activities of EstC at $\mathrm{NaCl}$ concentrations of 0, 2.5, 5, $7.5,10,12.5$, and $15 \%$ were $48.8 \pm 0.5,24.2 \pm 0.7,16.0$ $\pm 0.1,10.7 \pm 0.4,6.3 \pm 0.1,5.6 \pm 0.4$, and $4.6 \pm 0.05 \mu \mathrm{mol}$ $p$-nitrophenol/min/mg of protein, respectively. The specific activities of EstA at $\mathrm{NaCl}$ concentrations of 0, 2.5, $5,7.5,10,12.5,15,17.5$, and $20 \%$ were $32.6 \pm 0.3,46.3$ $\pm 0.2,47.5 \pm 0.1,47.5 \pm 0.2,47.4 \pm 0.3,51.0 \pm 0.5,41.6$ $\pm 0.6,40.1 \pm 0.1$, and $38.6 \pm 0.5 \mu \mathrm{mol} p$-nitrophenol/ $\mathrm{min} / \mathrm{mg}$ of protein, respectively.

The $\mathrm{pH}$ dependence of EstC stability and activity revealed a $\mathrm{pH}$ optimum of 5.5 to 6.0 on a Dixon-Webb plot (Figure 3). Since EstC was quite stable between $\mathrm{pH} 4.0$ and 8.0, the decline in activity with a decrease in $\mathrm{pH}$ from 5.5 to 4.0 can be attributed to the protonation of a single prototropic group with a $\mathrm{pK}_{\mathrm{a}}$ of about 4.4 to 4.5. The amino acid conferring this response is likely to be a Glu or Asp residue. The decline of enzyme activity with increasing $\mathrm{pH}$ above 6.0 can be attributed to the deprotonation of a single prototropic group with a $\mathrm{pK}_{\mathrm{a}}$ of about 6.9 to 7.0 , most likely conferred by a His (or possibly an unusual Cys) residue.

EstA was stable over the $\mathrm{pH}$ range of 6.0 to 10.0 , with a $\mathrm{pH}$ optimum for enzyme activity of 7.5 to 8.5 indicated on a Dixon-Webb plot (Figure 3). The pattern of decline of EstA activity in the acidic $\mathrm{pH}$ range is consistent with the protonation of two prototropic groups with a $\mathrm{pK}_{\mathrm{a}}$ of about 6.8 to 6.9 , and these groups are most likely to be His residues. The magnitude of the decline in EstA activity in the alkaline $\mathrm{pH}$ region examined was limited to $40 \%$ as one progressed from $\mathrm{pH} 8.0$ to 10.0. The midpoint of this decline in activity is consistent with the deprotonation of a prototropic group with $\mathrm{pK}_{\mathrm{a}}$ of about 8.7 to 8.8 , possibly conferred by a Cys (or unusual Lys or Tyr) residue.

Of the inhibitors analyzed, PCMB and Pepstatin A were most effective at inhibiting EstC activity (94\% 
$\mathbf{A}$

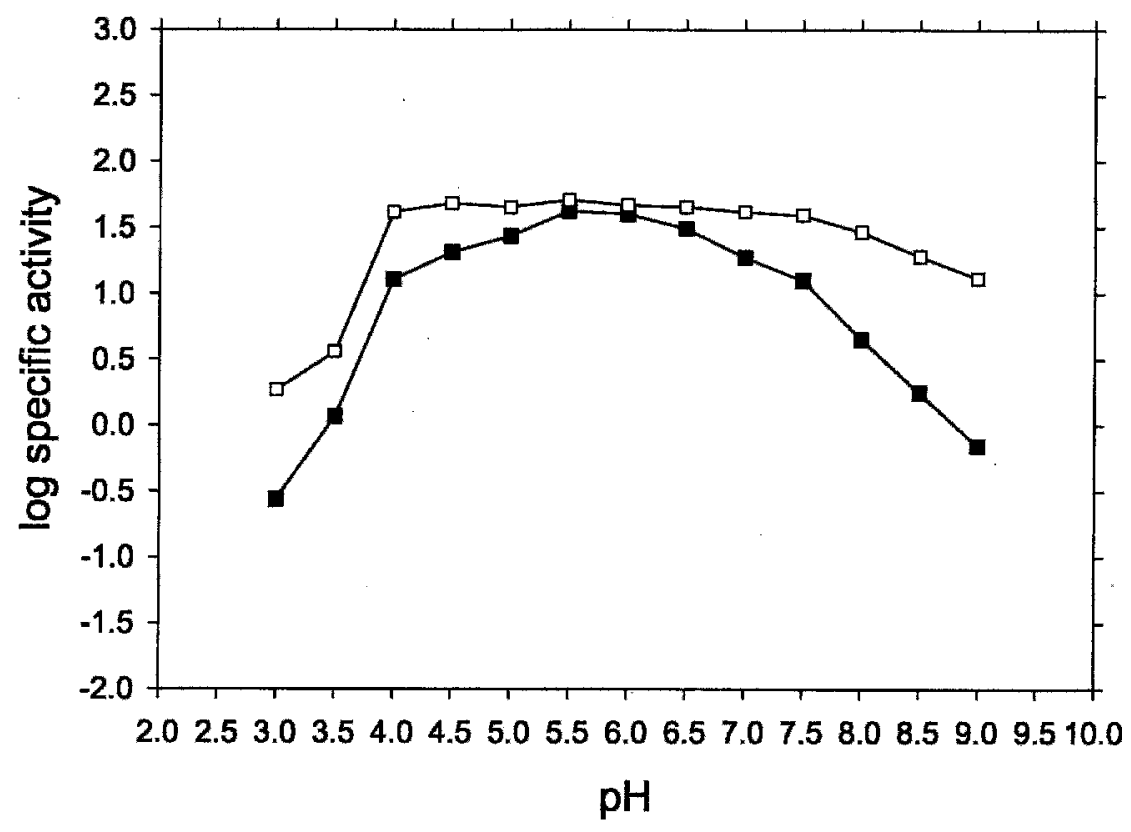

B

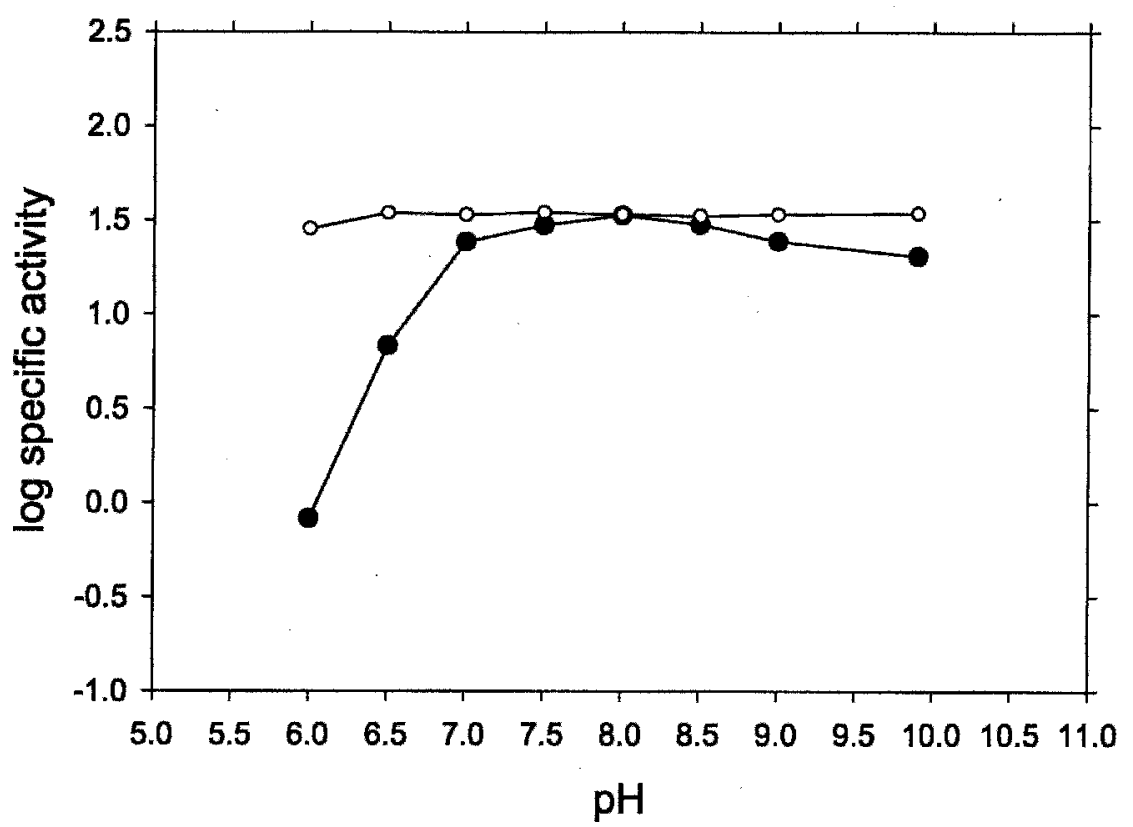

Figure 3. Effect of $\mathrm{pH}$ activity on purified EstC from Lactobacillus casei LILA (Panel A) and EstA from Lactococcus lactis MG1363 (Panel B). A. Effect of $\mathrm{pH}$ on EstC activity is represented by the closed symbol (ם) plot. Effect of $\mathrm{pH}$ on general enzyme stability of EstC is indicated by the open symbol $(\square)$ plot, which represents specific activity remaining after preincubating at respective $\mathrm{pH}$ values for 5 min and then assaying with $p$-nitrophenyl butanoate at $\mathrm{pH} 5.5$. B. Effect of $\mathrm{pH}$ on EstA activity is represented by the close symbol (-) plot. Effect of $\mathrm{pH}$ on general enzyme stability of EstA is indicated by the open symbol $(\bigcirc)$ plot, which represents specific activity remaining after preincubating at respective $\mathrm{pH}$ values for $5 \mathrm{~min}$ and then assaying with $p$-nitrophenyl butanoate at $\mathrm{pH}$ 7.5. 
and $80 \%$, respectively), implying that Cys and Asp/Glu residues are important for activity. However, EstC activity was only slightly inhibited by IAA $(11 \%)$, which is also a Cys-targeting inhibitor. Inhibition of EstC activity by PMSF (27\%) suggests that a His residue is also important for activity.

Inhibition of EstA activity by PCMB and IAA ( $>99 \%$ and $30 \%$, respectively), DFP ( $>99 \%), \operatorname{PMSF}(57 \%)$, and Pepstatin A (39\%) imply that Cys, Ser, His, and Asp/ Glu residues are important for EstA activity.

\section{Substrate Specificity of LILA EstC and MG1363 EstA}

The substrate specificity of purified EstC and EstA for different FA esters was determined using $p$ NP derivatives of $\mathrm{C} 2$ to $\mathrm{C} 16$, and ethyl esters of $\mathrm{C} 2$ to $\mathrm{C} 6 \mathrm{FAs}$ (Table 1). EstC was most selective for $p$ NP-C3 and $p$ NPC4, whereas EstA was most selective for $p$ NP-C5 and $p$ NP-C6. EstC and EstA were not active on $p$ NP ester substrates with acyl chain lengths longer than $\mathrm{C} 6$ and $\mathrm{C} 12$, respectively. EstC hydrolyzed ethyl esters of C2 to $\mathrm{C} 6$ fatty acids and was most selective for ethyl butanoate. However, EstA hydrolyzed only ethyl butanoate, ethyl pentanoate, and ethyl hexanoate within this same substrate series and was most selective for ethyl hexanoate.

The specificity of EstC and EstA toward alcohol functional groups was determined using acetate esters of a series of aromatic and short-chain alcohols (Table 1). Both EstC and EstA were active on aromatic ester substrates, such as phenyl acetate and phenylthioacetate, but EstC was $>1$ order of magnitude more selective for these substrates than EstA. EstC also hydrolyzed aliphatic alcohol derivatives consisting of propyl acetate, butyl acetate, and hexyl acetate, whereas activity of EstA on these substrates was BQL.

The hyperbolic plots generated from the kinetic data to predict $\mathrm{K}_{\mathrm{M}}$ and $\mathrm{V}_{\max }$ values using the Hyperbola (Hyperbol.fit) program of Sigma Plot 3.0 yielded reasonable fits $\left(R^{2}=0.977\right)$ to the experimental data.

\section{DISCUSSION}

This study focused on the biochemical characterization of an esterase identified from a genomic library of $L b$. casei LILA, and its comparison to a previously identified esterase (EstA) from Lc. lactis MG1363 (Fernández et al., 2000). Nucleotide sequencing of the esterase from $L b$. casei LILA, designated estC, revealed a $777 \mathrm{bp}$ ORF which could encode a protein of $28.9 \mathrm{kDa}$. The presence of putative transcriptional promoter sequences and lack of ORFs immediately upstream/downstream from estC, suggest that estC is transcribed mo- nocistronically. The absence of a rho-independent terminator sequence suggests that termination may occur by another mechanism (Washio et al., 1998).

Protein sequence alignment of EstC and $L b$. helveticus CNRZ32 EstA (Fenster et al., 2000) and Lc. lactis MG1363 EstA (Fernández et al., 2000) revealed 16.5 to $18.4 \%$ amino acid sequence identity with these enzymes. The low sequence homology observed between these esterases suggests that these enzymes are only distantly related to one another and may be responsible for the variation in esterase activity between these LAB.

The deduced amino acid sequence of EstC lacked a signal peptide (Izard and Kendall, 1994) at the N-terminus suggesting that this enzyme is located intracellularly. This observation is similar to those made for CNRZ32 EstA (Fenster et al., 2000) and MG1363 EstA (Fernández et al., 2000), which were also reported to lack secretion signal sequences. The intracellular location of these esterases suggests that cell lysis may be important for release and subsequent flavor formation by these enzymes during cheese ripening.

Activities of esterases and lipases are dependent upon a charge relay system involving an active-site SerAsp/Glu-His triad (Jaeger et al., 1999). The active-site serine of esterases and lipases is commonly conserved in a GXSXG motif in which $\mathrm{X}$ is a variable residue (Jaeger et al., 1999). The putative active-site serine of EstC is believed to reside in the deduced amino acid sequence GGSLG. The putative catalytic Asp/Glu and His residues of EstC were not identified, since the surrounding sequences for these residues are typically not highly conserved in esterases and lipases. The putative catalytic triad of EstA was previously identified by Fernández et al. (2000) to be Ser121, Asp202, and His 231 , and the putative active-site serine was observed to reside in a GXSXG pentapeptide.

The dependence of EstC activity on a Ser-Asp/GluHis catalytic triad was suggested by loss of $80 \%$ and $27 \%$ EstC activity with the Asp/Glu and His-targeting inhibitors, Pepstatin A and PMSF, respectively. Similar results were observed for EstA in which $49 \%$ and 57\% loss of EstA activity was observed with Pepstatin A and PMSF. However, EstA was inactivated by DFP whereas this inhibitor had no effect on EstC activity. The minimal effect that His and Ser-targeting inhibitors, PMSF and DFP, had on EstC activity, as compared to EstA activity, suggests that the EstC active-site serine is not as accessible as the EstA active-site serine for these inhibitors.

Inhibition of EstC activity was observed with the Cystargeting inhibitors, PCMB (94\%) and IAA (11\%), suggesting that an accessible cysteine residue is important for EstC activity. Similar results were observed for 
EstA which was inactivated by PCMB and had $30 \%$ loss of EstA activity with IAA. EstC has 3 cysteine residues (Cys33, Cys199, and Cys228) which could be accessible for reaction with PCMB and IAA. EstA has 1 cysteine residue (Cys198) which could be modulated by these Cys-targeting inhibitors. Given the bulkiness of the benzoate group of PCMB relative to the acetate group of IAA, reaction of PCMB with an accessible cysteine residue is likely to perturb the native conformations of EstC and EstA.

Greater selectivity of EstA and EstC for $p$ NP esters of C5-C6 and C3-C4 fatty acids, respectively, suggest that the substrate binding pocket of EstA is able to accommodate longer $n$-acyl chain lengths than EstC. In general, the increase in FA chain length from C3 to C6 had little effect on $\mathrm{K}_{\mathrm{M}}$ for EstC, however, it resulted in a progressive decrease in corresponding $\mathrm{V}_{\max }$. For EstA, increases in FA chain lengths from C3 to C12 resulted in progressive decrease in $\mathrm{K}_{\mathrm{M}}$, whereas declines in corresponding $\mathrm{V}_{\max }$ values did not occur until FA chain lengths exceeded C6. These trends suggest that the changes in selectivity within the series of substrates tested was influenced more by changes in $\mathrm{K}_{\mathrm{M}}$ for EstA than for EstC. For EstA, it appeared that the ability to stabilize the transition state of substrates is compromised by increasing FA chain length.

For both EstC and EstA, increases in FA chain length of ethyl esters from $\mathrm{C} 2$ to $\mathrm{C} 6$ and $\mathrm{C} 4$ to $\mathrm{C} 6$, respectively, resulted in decreasing $\mathrm{K}_{\mathrm{M}}$. For EstC, this resulted in a decrease in corresponding $\mathrm{V}_{\max }$ values, whereas for EstA, changes in corresponding $\mathrm{V}_{\max }$ values were minimal. These trends suggest that the changes in selectivity within this series of substrates tested was influenced by changes in $\mathrm{K}_{\mathrm{M}}$ for both EstC and EstA, but this did not compromise the ability to stabilize the transition state for EstA.

Comparison of EstC and EstA substrate selectivities towards ester substrates with $n$-acyl alcohol functional groups of $\mathrm{C} 2$ to $\mathrm{C} 6$ suggests that the alcohol binding pocket of EstC can accommodate longer $n$-chain lengths than EstA. The selectivity of EstC and EstA for aromatic ester substrates suggest that these enzymes have arylesterase activity and their alcohol binding pockets can accept large planar structures.

Esterases and lipases can mediate both the synthesis and hydrolysis of esters, with the equilibrium being dependent upon $\mathrm{a}_{\mathrm{w}}$ and cosubstrate levels (Ha and Lindsay, 1992; Jaeger et al., 1999; Law and Mulholland, 1995). During the long ripening time associated with Italian-type cheeses, selective decreases in free butanoic and hexanoic acids have been observed with concurrent formation of ethyl butanoate and ethyl hexanoate (Ha and Lindsay, 1992; Woo and Lindsay, 1984). These esters, which are potent flavor compounds at less than $5 \mathrm{mg} / \mathrm{kg}$, are important for development of the characteristic "fruity" flavors associated with Italiantype cheeses, such as Parmesan and Grana Padano, as well as "fruity" off-flavors in Cheddar cheese (Barbieri et al., 1994; Bills et al., 1965; Liu et al., 1998; Moio and Addeo, 1998). Ha and Lindsay (1992) found that a cheese base with $\mathrm{a}_{\mathrm{w}}$ of 0.75 to 0.90 had significantly lower free butanoic and hexanoic acid and higher ethyl butanoate and ethyl hexanoate in the presence of ethanol than a cheese base with an $\mathrm{a}_{\mathrm{w}}$ of 0.97 . Based on these results, Ha and Lindsay (1992) postulated that the decrease in $\mathrm{a}_{\mathrm{w}}$ associated with aging, as well as the formation of ethanol by the ripening microflora, favored the synthesis of these ethyl esters in Italian-type cheeses by esterases and lipases. Though the evidence provided by Ha and Lindsay (1992) is indirect, it suggests that at the beginning of ripening, hydrolysis of esters by esterases and lipases is favored by elevated $a_{w}$. However, as ripening proceeds, synthesis of esters by these enzymes is favored by decreasing $a_{w}$ and the presence of ethanol. Given the selectivity of EstC and EstA for short $n$-chain FAs and esters, EstC and EstA could have a significant effect on cheese flavor development.

Since EstC and EstA exhibit activity for phenylthioacetate, the thioesterase activity of these enzymes could contribute to cheese flavor development through hydrolysis or synthesis of thioesters. Given the limited information concerning the interaction of methanethiol with other compounds to form Cheddarlike flavors (Urbach, 1995), it is possible that thioesterases could mediate a step in this process. Hydrolysis of methylthioesters with release of methanethiol or synthesis of methylthioesters, such as methylthioacetate and methylthiopropionate, which have "cooked cauliflower" and "cheesy" flavors (Urbach, 1995) could occur depending on conditions within the cheese as it ripens. Formation of these compounds may have an important impact on cheese flavor development depending on the variety (Urbach, 1995).

The potential role of EstC and EstA in cheese flavor development is dependent upon their sensitivity to environmental conditions encountered in ripening cheese. Under conditions simulating cheese ripening $\left(10^{\circ} \mathrm{C}, 4 \%\right.$ $\mathrm{NaCl}, \mathrm{pH}$ 5.1), activity of EstA was found to be BQL, and activity of EstC was $25 \%$ relative to that observed under optimal conditions for this enzyme. The significant residual activity observed with EstC under cheeselike conditions suggests that this enzyme could play a role in modulating ester profiles during cheese ripening. Due to apparent inactivation of EstA activity under environmental conditions simulating cheese, the role of EstA in cheese flavor development may be limited. 
EstC is believed to be the first LAB esterase demonstrated to have optimum activity at $\mathrm{pH}$ values approaching that of cheese. This property distinguishes EstC from the esterases and lipases purified and characterized from Lb. casei (Castillo et al., 1999), Lb. plantarum (Gobbetti et al., 1996b; Gobbetti et al., 1997a), Lb. fermentum (Gobbetti et al., 1997b), Lb. helveticus (Fenster et al., 2000), Lc. lactis (Chich et al., 1997; Fernández et al., 2000; Holland and Coolbear, 1996; Tsakalidou and Kalantzopoulos, 1992), and St. thermophilus (Liu et al., 2001) which were reported to have optimum activities at $\mathrm{pH} 6.75$ to 8.0. EstC is also distinguished from the Lb. casei subsp. casei IFPL731 esterase characterized by Castillo et al. (1999) by differences in MW and substrate selectivity. The IFPL731 esterase was determined to have a monomeric $\mathrm{MW}$ of $38 \mathrm{kDa}$ under denaturing conditions as compared to $29 \mathrm{kDa}$ for EstC. Under nondenaturing conditions, EstC was determined to be a homodimer of $63 \mathrm{kDa}$ as compared to the IFPL731 esterase which was determined to be a homotrimer of $105 \mathrm{kDa}$. The substrate binding pocket of the IFPL731 esterase could accommodate FA chain lengths of $\mathrm{C} 4$ to $\mathrm{C} 14$, whereas the substrate binding pocket of EstC was limited to $n$-acyl chain lengths of C2 to $\mathrm{C} 6$.

\section{CONCLUSIONS}

The selectivity of EstC and EstA for short $n$-chain FA esters suggests that these enzymes could play an important role in cheese flavor development by modulating ester profiles in cheese. Since EstC and EstA were selective for hydrolyzing ethyl butanoate and ethyl hexanoate at elevated $a_{w}$, it is possible that these enzymes could synthesize these ethyl esters as $a_{w}$ decreases during ripening of lower moisture cheeses, such as Parmesan and Grana Padano. Evaluation of EstC and EstA under conditions simulating ripening cheese $\left(10^{\circ} \mathrm{C}, 4 \% \mathrm{NaCl}, \mathrm{pH} 5.1\right)$ revealed that EstC had greater activity and was less sensitive to cheeselike conditions than EstA. The increased activity of EstC under these conditions suggest that EstC would be more likely to have an impact on cheese flavor development than EstA. However, given the long ripening time of cheeses, such as Parmesan and Cheddar, both enzymes could influence cheese flavor development. To determine the role of EstC and EstA in cheese flavor development, isogenic strains differing in these activities will be constructed and evaluated in cheese trials.

\section{REFERENCES}

Altschul, S. F., W. Gish, W. Miller, E. W. Myers, and D. J. Lipman. 1990. Basic local alignment search tool. J. Mol. Biol. 215:403-410.
Anderson, D. G., and L. L. McKay. 1983. Simple and rapid method for isolating large plasmid DNA from lactic streptococci. Appl. Environ. Microbiol. 46:549-552.

Barbieri, G., L. Bolzoni, M. Careri, A. Mangia, G. Parolari, S. Spagnoli, and R. Virgili. 1994. Study of the volatile fraction of Parmesan cheese. J. Agric. Food Chem. 42:1170-1176.

Battistotti, B., and C. Corradini. 1993. Italian cheese. Pages 221-244 in Cheese: Chemistry, Physics, and Microbiology, Vol. 2. P.F. Fox, ed. Chapman \& Hall, London, United Kingdom.

Beresford, T. P., N. A. Fitzsimons, N. L. Brennan, and T. M. Cogan. 2001. Recent advances in cheese microbiology. Int. Dairy J. 11:259-274.

Bills, D. D., M. E. Morgan, L. M. Libbey, and E. A. Day. 1965. Identification of compounds responsible for fruity flavor defect of experimental Cheddar cheeses. J. Dairy Sci. 48:1168-1173.

Castillo, I., T. Requena, P. Fernandez de Palencia, J. Fontecha, and M. Gobbetti. 1999. Isolation and characterization of an intracellular esterase from Lactobacillus casei subsp. casei IFPL731. J. Appl. Microbiol. 86:653-659.

Chich, J.-F., K. Marchesseau, and J.-C. Gripon. 1997. Intracellular esterase from Lactococcus lactis subsp. lactis NCDO 763: Purification and characterization. Int. Dairy J. 7:169-174.

De Man, J. C., M. Rogosa, and M. E. Sharpe. 1960. A medium for the cultivation of lactobacilli. J. Appl. Bacteriol. 23:130-135.

Dumont, J. P., S. Roger, and J. Adda. 1974. Composés volatils du fromage entier et du fromage râpé: Exemple du Parmesan. Lait 54:386-396.

Fenster, K. M., K. L. Parkin, and J. L. Steele. 2000. Characterization of an arylesterase from Lactobacillus helveticus CNRZ32. J. Appl. Microbiol. 88:572-583.

Fernández, L., M. M. Beerthuyzen, J. Brown, R. J. Siezen, T. Coolbear, R. Holland, and O. P. Kuipers. 2000. Cloning, characterization, controlled overexpression, and inactivation of the major tributyrin esterase gene of Lactococcus lactis. Appl. Environ. Microbiol. 66:1360-1368.

Fox, P. F., T. K. Singh, and P. L. H. McSweeney. 1995. Biogenesis of flavour compounds in cheese. Pages 59-98 in Chemistry of Structure-Function Relationships in Cheese. E. L. Malin and M. H. Tunick, ed. Plenum Press, New York, NY.

Fox, P. F., T. P. Guinee, T. M. Cogan, and P. L. H. McSweeney. 2000. Cheese Flavor. Pages 236-278 in Fundamentals of Cheese Science. J. Colilla, ed. Aspen Publishers, Inc., Gaithersburg, MD.

Gobbetti, M., P. F. Fox, and L. Stepaniak. 1996a. Esterolytic and lipolytic activities of mesophilic and thermophilic lactobacilli. Italian J. Food Sci. 2:127-135.

Gobbetti, M., P. F. Fox, E. Smacchi, L. Stepaniak, and P. Damiani. 1996b. Purification and characterization of a lipase from Lactobacillus plantarum 2739. J. Food Biochem. 20:227-246.

Gobbetti, M., P. F. Fox, and L. Stepaniak. 1997a. Isolation and characterization of a tributyrin esterase from Lactobacillus plantarum 2739. J. Dairy Sci. 80:3099-3106.

Gobbetti, M., E. Smacchi, and A. Corsetti. 1997b. Purification and characterization of a cell surface-associated esterase from Lactobacillus fermentum DT41. Int. Dairy J. 7:13-21.

Ha, J. K. and R. C. Lindsay. 1992. Influence of $\mathrm{a}_{\mathrm{w}}$ on volatile free fatty acids during storage of cheese bases lipolyzed by kid goat pregastric lipase. Int. Dairy J. 2:179-195.

Ha, J. K. and R. C. Lindsay. 1993. Release of volatile branched-chain and other fatty acids from ruminant milk fats by various lipases. J. Dairy Sci. 76:677-690.

Holland, R., and T. Coolbear. 1996. Purification of tributyrin esterase from Lactococcus lactis subsp. cremoris E8. J. Dairy Res. 63:131-140.

Hofmann, K., P. Bucher, L. Falquet, and A. Bairoch. 1999. The PROSITE database, its status in 1999. Nucleic Acids Res. 27:215-219.

Izard, J. W., and D. A. Kendall. 1994. Signal peptides: Exquisitely designed transport promoters. Mol. Microbiol. 13:765-773.

Jaeger, K.-E., B. W. Dijkstra, and M. T. Reetz. 1999. Bacterial biocatalysts: Molecular biology, three-dimensional structures, and biotechnological applications of lipases. Ann. Rev. Microbiol. 53:315-351. 
Johnson, M. E. 2001. Cheese products. Pages 345-384 in Applied Dairy Microbiology. E. H. Marth and J. L. Steele, ed. Marcel Dekker, Inc., New York, NY.

Kunst, F., N. Ogasawara, I. Moszer, A. M. Albertini, G. Alloni, V. Azevedo, M. G. Bertero, P. Bessières, A. Bolotin, S. Borcher, R. Borriss, L. Boursier, A. Brans, M. Braun, S. C. Brignell, S. Bron, S. Brouillet, C. V. Bruschi, B. Caldwell, V. Capuanos, N. M. Carter, S.-K. Choi, J.-J. Codani, I. F. Connerton, N. J. Cummings, R. A. Daniel, F. Denizot, K. M. Devine, A. Düsterhöft, S. D. Ehrlichs, P. T. Emmerson, K. D. Entian, J. Errinton, C. Fabret, E. Ferrari, D. Foulger, C. Fritz, M. Fujita, Y. Fujita, S. Fuma, A. Galizzi, N. Galleron, S.-Y. Ghim, P. Glaser, A. Goffeau, E. J. Golightly, G. Grandi, G. Guiseppi, B. J. Guy, K. Haga, J. Haiech, C. R. Harwood, A. Hénaut, H. Hilbert, S. Holsappel, S. Hosono, M.-F. Hullo, M. Itaya, L. Jones, B. Joris, D. Karamata, Y. Kasahara, M. Klaerr-Blanchard, C. Klein, Y. Kobayashi, P. Koetter, G. Koningstein, S. Krogh, M. Kumano, K. Kurita, A. Lapidus, S. Lardinois, J. Lauber, V. Lazarevic, S.-M. Lee, A. Levine, H. Liu, S. Masuda, C. Mauël, C. Médigue, N. Medina, R. P. Mellado, M. Mizuno, D. Moestl, S. Nakai, M. Noback, D. Noone, M. O'Reilly, K. Ogawa, A. Ogiwara, B. Oudega, S.-H. Park, V. Parro, T. M. Pohl, D. Portetelle, S. Porwollik, A. M. Prescott, E. Presecan, P. Pujic, B. Purnelle, G. Rapoporti, M. Rey, S. Reynolds, M. Rieger, C. Rivolta, E. Rocha, B. Roche, M. Rose, Y. Sadaie, T. Sato, E. Scanlan, S. Schleich, R. Schroeter, F. Scoffone, J. Sekiguchi, A. Sekowska, S. J. Seror, R. Serrors, B.-S. Shin, B. Soldo, A. Sorokin, E. Tacconi, T. Takagi, H. Takahashi, K. Takemaru, M. Takeuchi, A. Tamakoshi, T. Tanaka, P. Terpstra, A. Tognoni, V. Tosato, S. Uchiyama, M. Vandenbol, F. Vannier, A. Vassarotti, A. Viari, R. Wambutt, E. Wedler, H. Wedler, T. Weitzenegger, P. Winters, A. Wipat, H. Yamamoto, K. Yamane, K. Yasumoto, K. Yata, K. Yoshida, H.-F. Yoshikawa, E. Zumstein, H. Yoshikawa, and A. Danchin. 1997. The complete genome sequence of the gram-positive bacterium Bacillus subtilis. Nature 390:249-256.

Law, B. A., and F. Mulholland. 1995. Enzymology of lactococci in relation to flavour development from milk proteins. Int. Dairy J. 5:833-854.

Liu, S.-Q., R. Holland, V. L. Crow. 1998. Ethyl butanoate formation by dairy lactic acid bacteria. Int. Dairy J. 8:651-657.

Liu, S.-Q., R. Holland, V. L. Crow. 2001. Purification and properties of intracellular esterases from Streptococcus thermophilus. Int. Dairy J. 11:27-35.

Marmur, J. 1961. A procedure for the isolation of deoxyribonucleic acid from microorganisms. J. Mol. Biol. 3:208-218.
Martin, C. J., J. Golubow, and A. E. Axelrod. 1959. A rapid and sensitive spectrophotometric method for the assay of chymotrypsin. J. Biol. Chem. 234:294-298.

McSweeney, P. L. H., and M. J. Sousa. 2000. Biochemical pathways for the production of flavour compounds in cheeses during ripening: A review. Lait 80:293-324.

Meinhart, E., and P. Schreier. 1986. Study of flavour compounds from Parmigiano Reggiano cheese. Milchwissenschaft 41:689-691.

Moio, L., and F. Addeo. 1998. Grana Padano cheese aroma. J. Dairy Res. 65:317-333.

Person, W. R., T. Wood, Z. Zhang, and W. Miller. 1997. Comparison of DNA sequences with protein sequences. Genomics. 46:24-36.

Sambrook, J., E. F. Fritsch, and T. Maniatis. 1989. Molecular Cloning: A Laboratory Manual, 2nd ed. Cold Spring Harbor Laboratory, Cold Spring Harbor, NY.

Shine, J., and L. Dalgarno. 1974. The 3'-terminal sequence of Escherichia coli $16 \mathrm{~S}$ ribosomal RNA: Complementarity to nonsense triplets and ribosome binding sites. Proc. Nat. Acad. Sci. USA. 71:1342-1346.

Stover, C. K., X. -Q. T. Pham, A. L. Erwin, S. D. Mizoguchi, P. Warrener, M. J. Hickey, F. S. L. Brinkman, W. O. Hufnagle, D. J. Kowalik, M. Lagrou, R. L. Garber, L. Goltry, E. Tolentino, S. Westbrook-Wadman, Y. Yuan, L. L. Brody, S. N. Coulter, K. R. Folger, A. Kas, K. Larbig, R. M. Lim, K. A. Smith, D. H. Spencer, G. K. S. Womg, Z. Wu, I. T. Paulsen, J. Reizer, M. H. Saier, R. E.W. Hancock, S. Lory, and M. V. Olson. 2000. Complete genome sequence of Pseudomonas aeruginosa PA01, an opportunistic pathogen. Nature 406:959-964.

Tsakalidou, E. and G. Kalantzopoulos. 1992. Purification and partial characterization of an esterase from Lactococcus lactis ssp lactis strain ACA-DC 127. Lait 72:533-543.

Urbach, G. 1995. Contribution of lactic acid bacteria to flavour compound formation in dairy products. Int. Dairy J. 5:877-903.

Washio, T., J. Sasayama, and M. Tomita. 1998. Analysis of complete genomes suggests that many prokaryotes do not rely on hairpin formation in transcription termination. Nucleic Acids Res. $26: 5456-5463$.

Woo, A. H., S. Kollodge, and R. C. Lindsay. 1984. Quantification of major free fatty acids in several cheese varieties. J. Dairy Sci. 67:874-878.

Woo, A. H., and R. C. Lindsay. 1984. Concentrations of major free fatty acids and flavor development in Italian cheese varieties. J. Dairy Sci. 67:960-968. 